\title{
Comparative Analysis of Battery Cage and Deep Litter Poultry Housing Systems in Abia State, Nigeria 10.29023/alanyaakademik.350986
}

\author{
C. I. OKPOKIRI, N.M AGWU, C.N ONWUSIRIBE \\ Department of Agribusiness and Management, Michael Okpara University of Agriculture \\ Umudike, Abia State, Nigeria (ndubuisichigo@gmail.com) Phone: +2348063724608
}

\begin{abstract}
Keywords:

The study was centered on the comparative analysis of battery cage and deep litter poultry housing systems in Abia state, Nigeria. The study

Deeplitter

Battery cage

Poultry

Profitability

Housing systems

Received: 23.06 .2017

Accepted: 10.10 .2017 specifically examined the factors influencing the choice of poultry housing system in the study area; estimated the profitability of battery cage and deep litter system in the area; analyzed the determinants of profit in battery cage and deep litter systems respectively; and examined the constraints faced by poultry farmers in the area. Primary data source was used for the study. Multi-stage sampling technique was used in the selection of 140 respondents. Descriptive statistics like frequency, tables, charts, etc; profitability index (cost and returns analysis) and multiple regression were the tools of analysis. From the cost and return analysis, it was observed that both housing systems are profitable. The t test result showed that housing system adopted for poultry farms have an effect on the profit. However, it was observed that farmers using deep litter system make more profit when compared to battery cage housing system. It was observed that battery cage system is more capital intensive when compared to deep litter system and this predisposes most famers to favour deep litter housing system to battery cage system. Sex, marital status, education, mortality rate, cost of production, farm size, experience and access to credit were significant variables having varying effects on the profit of battery cage users while sex, household size, education, mortality, cost of production, farm size, experience were the significant variables influencing the returns of deep litter users in the study area. High cost of feeds, inadequate amenities, high interest rates, quality of stock etc. where the major constraints of poultry production in the area. The study recommends that governments should subsidize the cost of feeds to make it affordable for farmers in the study area.
\end{abstract}

\section{INTRODUCTION}

Overtime Agriculture has been the major source of income, livelihood option and employment in Nigeria and other West African countries. It employed about $70 \%$ of the Nigerians' population as at 2010 (Labour force statistics, 2010). As the unemployment rate grows geometrically in Nigeria, people strive for ways to make a living and one of such ways is poultry production. Many unemployed people earn a living from poultry production. Generally, poultry production is known to have some advantages over other forms of 
livestock production. Some of these advantages are: its little capital requirement to set up, simple management practices, its ability to grow and mature fast, and its widespread consumption among religion and health circles, among others. Chickens and eggs contribute to a nutritious, balanced diet, which is especially important for children, nursing mothers and people who are ill (ACIAR, 2009). Poultry production is the rearing of domesticated farm birds such as fowl, quail, turkey, duck, geese etc. for meat, egg, feather and other economic purpose. The success of every poultry farm is hinged on good management system and the housing system adopted. Housing system is sacrosanct because it determines to a large extent the returns to the farmer. There are three major housing systems practiced in Nigeria namely free range, battery cage and deep litter system. The study concentrated on battery cage and deep litter housing systems.

In battery cage system, a metal cage is used divided compartment containing one or two birds per cage arranged in rows. It has its advantages as birds are easily managed, facilitates maintenance of farm records, easy control of disease outbreak and easy identification and culling of sick birds. Its disadvantages include Cage fatigue which is considered to a physiological derangement of mineral electrolytes imbalance. Leg weakness is also common in caged bird; it is expensive system of housing birds and the system is mainly used for egg production.

Battery cage system denies chickens direct access to their faeces. This wholly translates to reduced risk of infection and medication costs, lowering the overall cost of production. Whereas for floor birds who have direct access to their faeces, picking up their faeces with food as well as ammonia build up can constitute serious health risks. Stock taking is much easier in a battery cage. Even if there are tens of thousands of broiler or layer birds on the farm, the owner or manager can easily count his birds. This exercise would be very difficult to carry out in deep litter system where they birds are moving about constantly. Farm hands find it easier to steal from the flock in a deep litter system(practical business ideas,2016).Fatty live syndrome is a problem met with caged layers due to increased deposition of fat in the body resulting in death due to internal hemorrhage but under deep litter system birds move around and the threat of fatty live syndrome is not common place. Also, there are difficulties in ensuring proper ventilation to birds especially in summer season and under very high dense conditions which leads to Hysteriosis of caged birds while deep litter is roomy and well ventilated when compared with caged birds (Tnau agritech portal, 2015).

Both battery cage and deep litter systems have its advantages and disadvantages and the housing system adopted by farmers is based on some factors like personal preference, cost, space available, number of birds and management practice adopted. Housing system adopted determines to a large extent determines the success of the farms because farms birds are fragile and if they are not kept in a conducive environment, may develop complications and eventual death leading to loss of investment. Poultry farmers strive to choose a housing system that will provide the desired environment that will encourage optimum production of the birds and increases the farmers' chance on return of his investment. The study comparatively analyzed the battery cage and deep litter housing systems in the study area in order to determine the profitability levels in the area. The objectives of the study were to: 
i. examine the factors influencing the choice of poultry housing system in the study area;

ii. estimate the profitability of battery cage and deep litter system in the area;

iii. analyze the determinants of profit in battery cage and deep litter systems respectively;

iv. describe the constraints faced by poultry farmers in the area.

\section{MATERIALS AND METHOD}

This study was carried out in Abia State, Nigeria. Abia state was created in 1991 having been carved out from the old Imo State. The citizens are predominantly Igbos. Abia state is located in the south eastern region of Nigeria. The state is approximately within latitudes $4^{\circ} 41^{\prime}$ and $6^{\circ} 14^{\prime}$ north of the equator and longitudes $7^{\circ}, 10^{\prime}$ and $8^{\circ}$ east of the Greenwich meridian. It has seventeen Local Government Areas that are divided into three senatorial zones, namely: Abia north, Abia south and Abia central (ABSEEDS, 2003).In agriculture, the state is divided into three agricultural zones, namely Umuahia, Aba, and Ohafia. Major agricultural produce includes maize, yam, plantain, rice, vegetable, melon, beans etc. livestock reared in the area include goat, sheep, pigs, poultry and fish.

The data were collected from primary sources. The primary data were collected using a well structured questionnaire and interview sessions. Multi-stage sampling technique was used in the selection of the respondents. In the first stage, the three agricultural zones was chosen. In the second stage, five local government areas were chosen purposively based on the existence of poultry farmers in the areas. In the third stage, two villages were chosen from each of the local government areas to give 10 villages and 14 poultry farmers were selected, 7 farmers who used deep litter system and the other 7 battery cage; bringing the sample size to a total of 140 respondents.

\subsection{Method of Data Analysis}

Objectives one and four were analyzed using descriptive statistics like frequency, tables, charts, etc. objective two was analyzed with profitability index (cost and returns analysis) and finally multiple regression was used to achieve objective three.

\subsection{Model Specification}

The cost and returns was analyzed using profitability analysis

$$
\pi=T R-T C
$$

Where

$\pi=$ Profit (Naira)

$\mathrm{TR}=$ Total revenue (Naira)

$\mathrm{TC}=$ Total Cost (Naira)

$\mathrm{TR}=\mathrm{PQ}$

$\mathrm{P}=$ price per unit of output (Naira)

$\mathrm{Q}=$ Quantity of output (number of birds)

$\mathrm{TC}=\mathrm{TVC}+\mathrm{TFC}$

Where

TVC $=$ Total Variable Cost (Naira)

TFC $=$ Total Fixed Cost (Naira)

The explicit form of the regression model is stated as 
$\mathrm{Y}_{1}=\mathrm{b}_{0}+\mathrm{b}_{1} \mathrm{x}_{1}+\mathrm{b}_{2} \mathrm{x}_{2}+\mathrm{b}_{3} \mathrm{x}_{3}+\mathrm{b}_{4} \mathrm{x}_{4}+\mathrm{b}_{5} \mathrm{x}_{5}+\mathrm{b}_{6} \mathrm{x}_{6}+\mathrm{b}_{7} \mathrm{x}_{7}+\mathrm{b}_{8} \mathrm{X}_{8}+\ldots+\mathrm{b}_{\mathrm{n}} \mathrm{x}_{\mathrm{n}}+\mathrm{e} i$

Where;

$\mathrm{Y}=$ returns of poultry farmers in naira

$\mathrm{X}_{1}=\operatorname{sex}($ male $=1$ and female $=0)$

$\mathrm{X}_{2=}$ marital status(married $=1$ and otherwise $=0$ )

$\mathrm{X}_{3}=$ household size measured in numbers

$\mathrm{X}_{4}=$ level of education of the famer measured in years

$\mathrm{X}_{5}=$ mortality rate measured in naira

$\mathrm{X}_{6}=$ cost of production measured in naira

$\mathrm{X}_{7=}$ labour measured in naira

$\mathrm{X}_{8}=$ farm size measured by the number of birds in thefarm

$\mathrm{X}_{9}=$ experience of the farmers measured in years

$\mathrm{X}_{10}=$ loan size measured in naira

$\mathrm{B}_{\mathrm{i}}=$ the parameter

$\mathrm{E}_{\mathrm{i}}=$ the error term

\section{RESULTS AND DISCUSSIONS}

\subsection{Factors Influencing the Choice of Poultry Housing System}

Table1: factors influencing choice of poultry housing system

\begin{tabular}{lllll}
\hline & \multicolumn{2}{c}{ Battery cage } & \multicolumn{2}{c}{ Deep litter } \\
\hline Factors & Frequency=70 & Percentage & Frequency=70 & Percentage \\
Cost & 48 & 68.6 & 65 & 92.9 \\
Birds health & 36 & 51.4 & 27 & 38.6 \\
Access to fund & 55 & 78.6 & 52 & 74.3 \\
Management ease & 55 & 78.6 & 42 & 60 \\
Mortality rate & 39 & 55.7 & 23 & 32.9 \\
purposeof bird & 48 & 68.6 & 55 & 78.6 \\
production & & & & 70 \\
Labour intensive & 36 & 51.4 & 49 & \\
\hline Source: fid
\end{tabular}

Source: field survey,2016. Multiple responses recorded

The results showed that $68.6 \%$ of the respondents chose battery cage system because of cost involved. They believe that the system was within their budget, cost effective and little wastes recorded in terms of feed and water. Battery cage system also requires little space with ease of mechanization. For deep litter system,92.2\% of the respondents chose deep litter system because it is less expensive when compared to the battery cage. Given this, many rural farmers prefer to rear their birds under the deep litter system. This is exacerbated by their inability to access credit, which restricts the farmers' ability to purchase required inputs. The litters are gotten from wood shavings at no cost at all. Cost played a huge role in the choice of housing system adopted. From the result, it was observed that battery cage was mainly used by farmers with huge capital while farmers with inadequate capital favour deep litter.

Health of the birds influenced $51.4 \%$ of the respondents' decision in choosing battery cage while $38.6 \%$ opted for deep litter system. The farmers indicated that battery cage system 
makes it easy to identify sick birds and unproductive birds, either to have them treated or cull them. It also reduces the chances of a full blown pest and disease outbreak in the farm.

Farmers using deep litter believed that on the grounds of the health of birds, deep litter system is best preferred as birds have enough room to move around and exercise. They also reasoned that birds housed in deep litters have their natural habitat environment which increases their production and most health hazards like cage fatigue, hemorrhage etc caused by little or no movement of birds are not common place.

Access to fund had an effect on $78.6 \%$ choosing battery cage system and $74.3 \%$ deep litter system. This is the major influence on the choice of housing system to use as farmers go for the housing system they can afford. Most farmers who chose battery cage system have better access to fund than deep litter users.

Birds under battery cage are easily managed as the birds are in a place and require fewer hands to take care them as believed by $78.6 \%$ of the respondents. The birds are neat and healthy because the birds have no contact with their waste. The system helps in identification of sick birds and runts from the park. Management of birds in deep litter is better as believed by $60 \%$ of the respondents chose deep litter system because the deemed it better as they have enough hands helping in the day to day affairs of the birds. They identify birds that are slow or weak and give the needed attention to them.

The mortality rates have an influence on the choice of housing system, $55.7 \%$ of the respondents opined that mortality rate with battery cage system is very low because of the attention and ease identification of sick birds and the system reduces the chances of epidemic in the farm. For deep litter system, 32.9\% of the farmers interviewed using deep litter system reasoned that the mortality rate is low as birds have enough room to move around which makes them strong and fit to resist diseases. Also, constant check by the farmers helps cull sick ones. Most of farmers agreed that in times of epidemic which are usually rare, the effect is disastrous as the disease can easily be transferred from one bird to another.

The purpose of keeping the birds also has an effect on the housing system adopted. $68.6 \%$ of the respondents chose battery for this purpose while $78.6 \%$ chose deep litter. It was observed that most farmer who keep the poultry birds for meat (chicken) prefer to use the battery cage system. The birds have little room to roam about and spend most of their time eating and adding weight. Most of the farmers who are interested in egg production prefer deep litter system because there is enough room for the birds to move around and keep fit. Also, there is enough space to accommodate the eggs.

The labour requirements of the housing system adopted play a major role in the choice of housing system; $51.4 \%$ of the respondents chose battery cage because its labour needs is quite minimal. Few hands are needed to provide food and water and take her of the birds. The labour requirement in deep litter is on the high side but $70 \%$ of the respondents who chose deep litter have the required labour to take care of the farm. Most of the farmers have large household sizes which serve as a source of cheap labour to the farm. 


\subsection{Profitability of battery cage and deep litter system in the area}

The results in Table 2 shows the cost and return analysis of battery cage and deep litter housing systems in the study area.

Table 2: costs and return analysis of battery cage and deep litter housing system in the area

\begin{tabular}{|c|c|c|c|c|c|c|}
\hline & \multicolumn{3}{|c|}{ Battery cage } & \multicolumn{3}{|c|}{ Deep litter } \\
\hline Variables & Qty & $\begin{array}{l}\text { Unit } \\
\text { price } \\
\text { N }\end{array}$ & $\begin{array}{l}\text { Total cost } \\
\text { N }\end{array}$ & Qty & $\begin{array}{l}\text { Unit } \\
\text { price } \\
\text { N }\end{array}$ & $\begin{array}{l}\text { Total cost } \\
\text { N }\end{array}$ \\
\hline \multicolumn{7}{|l|}{ Revenue } \\
\hline Sales & 591 birds & 1800 & 1063800 & 578 birds & 1800 & 1040400 \\
\hline Manure & 30 bags & 1000 & 30000 & 15bags & 1000 & 15000 \\
\hline Total revenue & & & 1093800 & & & 1055400 \\
\hline \multicolumn{7}{|l|}{ Fixed cost } \\
\hline Housing & 5 cages & 98000 & 490000 & 4 rooms & & 250000 \\
\hline \multirow[t]{4}{*}{ Equipments } & 1 generator & 45000 & 45000 & 1 generator & 45000 & 45000 \\
\hline & 8 feeders & 700 & 5600 & 12 feeders & 700 & 8400 \\
\hline & 6 drinkers & 500 & 3000 & 9 drinkers & 500 & 4500 \\
\hline & 3 debeaker & 1000 & 3000 & 2 debeaker & 1000 & 2000 \\
\hline Total fixed cost & & & 546600 & & & 309900 \\
\hline Variable cost & & & & & & \\
\hline Birds & 600 birds & 150 & 90000 & 600 birds & 150 & 90000 \\
\hline Feeds & 73Bags & 3500 & 255500 & 76 bags & 3500 & 266000 \\
\hline Water & 2 tanks & 2500 & 5000 & 3 tanks & 2500 & 7500 \\
\hline Medications & & & 6950 & & & 12000 \\
\hline Litter material & & & & & & 2000 \\
\hline Labour & 3 & 10000 & 30000 & 5 & 10000 & 50000 \\
\hline Electricity bill & & & 5000 & & & 9000 \\
\hline Transportation & & & 2500 & & & 3500 \\
\hline Food supplements & 2bags & 2000 & 2000 & & 2.5bags & 5000 \\
\hline Total variable cost & & & 396950 & & & 445000 \\
\hline Total cost & & & 943550 & & & 754900 \\
\hline Gross margin & & & 696850 & & & 610400 \\
\hline Net farm income & & & 150250 & & & 300500 \\
\hline $\begin{array}{l}\text { Return on } \\
\text { investment }\end{array}$ & & & 15.9 & & & 39.8 \\
\hline $\begin{array}{l}\text { Operating } \\
\text { ratio(OR) }\end{array}$ & & & 0.36 & & & 0.42 \\
\hline
\end{tabular}

Source: field survey, 2016

From results in Table 2, it was observed that the battery cage housing system has a high fixed cost at \$546, 600.00 when compared to deep litter system whose fixed cost was \$309, 900.00. This shows that battery cage housing system is more capital intensive compared deep litter system. The total variable cost for battery cage was $\$ 396,950.00$ and $\$ 445,000.00$ for deep litter system. This shows that battery cage system has a lower variable cost to deep litter system. By implication, the deep liter system is more expensive as extra costs are incurred in the cost of running the business. Cost of feeding the birds accounted for the bulk of the variable cost for battery cage and deep litter system at $\$ 255,500.00$ and $\$ 266,000.00$ 
respectively. This finding is in agreement with those of Okezie and Bime (2006), Mgbakor and Chinonso (2013), and Adebayo et al (2015). They confirmed from their various studies that cost of feed constituted the highest share of total cost in poultry production in Cross River, Anambra and Kwara States of Nigeria respectively. This was followed by the cost of birds which was $\$ 90000$ for 600 birds for both battery cage and deep litter systems. Other variable cost factors include water cost, transportation cost, feed supplements, labour, litter materials for deep litter system etc. the total revenue gotten from gotten from both the sale of birds and manure (bird waste) amounted to $\$ 1093800$ for battery cage system and $\$ 1055400$ for deep litter. The gross profit for battery cage was $\$ 696850$ and $\$ 610400$ for deep litter. Both systems had a positive gross margin which shows that the enterprises can offset the cost of running the business. The net returns were positive also with battery cage having $\$ 150250$ and $\$ 300500$ for deep litter system. Deep litter system had a very high net profit and farmers are likely to favour deep litter to battery cage.

The return on investment showed that for every naira invested in battery cage will yield $\$ 15.9$ in return and for every naira invested using the deep litter system will yield $\$ 39.8$. This showed that both housing system are quite profitable. The operating ratio also shows that the both housing system are profitable with 0.36 and 0.42 respectively. The operating ratio shows that the battery cage system is better to deep litter system as the lower the operating ratio, the higher the profit.

The result of the cost and return analysis show that both housing systems are profitable. It also shows that battery cage system is capital intensive when compared to deep litter system and this engenders most famers to favour deep litter housing system to battery cage system.

Battery cage system seems to be more economical because it ensures little to no waste in resources especially feeds and water and feeding the birds is a lot easier than deep litter system. Birds under battery cage system are healthy as they have no access to their waste. This reduces infection in $\mathrm{n}$ the farms and medication fees in the farm is reduced as birds are neat and healthy. These assertions were supported by Lamidi (2014), who found out that there was a significant difference observed between the weights of broilers and different housing systems with birds housed in battery cage having more weight gains than birds housed in deep litter and pens. This helps farmers using battery cage to command higher prices for their birds in the market.

\subsection{Independent Samples Test on the profitability of the housing systems}

An independent $t$ test was conducted to compare the profitability of battery cage housing system and deep litter system of poultry farms.

Table 3: Independent Samples Test on the profitability of battery cage and deep litter poultry housing systems

\begin{tabular}{llll}
\hline Housing systems & Sample size & Mean & Standard deviation \\
\hline Deep litter & 70 & 4.4690 & .77615 \\
Battery cage & 70 & 3.7803 & .31638 \\
$\mathbf{T}(\mathbf{1 4 . 1})=\mathbf{5 4 . 3}, \mathbf{P}=\mathbf{0 . 0 4 2}$ & & & \\
\hline
\end{tabular}

Source: field survey: 2016 
From the $\mathrm{t}$ test result, a significant difference of profit for deep litter system $(\mathrm{M}=4.5$, $\mathrm{SD}=0.77)$ and battery cage system $(\mathrm{M}=3.8, \mathrm{SD}=0.32)$ conditions; $\mathrm{t}(14.1)=54.3, \mathrm{P}=0.042$. The $\mathrm{t}$ test results shows that farmers using deep litter system make more profit when compared to battery cage housing system in the study area. This is going by the difference in the $\mathrm{t}$ - test result, which showed a statistical difference between the means in profit of the two housing systems.

\subsection{Determinants of Profit in Battery Cage and Deep Litter Systems}

Tables $4 \& 5$, shows the results of the estimates of the factors that determine profit in battery cage housing system and deep litter housing systems.

Table 4: estimates of determinants of profit in battery cage system in the study area

\begin{tabular}{lllll}
\hline Variables & Linear & Exponential & Double log & Semi $\log ^{+}$ \\
\hline Intercept & 40146.76 & 11.0169 & 9.859 & 6.10149 \\
Sex & $(2.74)^{* * *}$ & $(74.75)^{* * *}$ & $(27.36)^{* * *}$ & $(6.12)^{* * *}$ \\
& 878.052 & 0061982 & 089105 & 10896.37 \\
Marital status & $(1.95)^{*}$ & $(1.32)^{*}$ & $(2.71)^{* * *}$ & $(3.36)^{* * *}$ \\
& 202.478 & 0006732 & 0240633 & -91.263 \\
Household size & $(1.23)$ & $(0.41)$ & $(0.38)$ & $(-2.83)^{* * *}$ \\
& 688.806 & 013014 & 0175057 & -905.634 \\
education & $(1.13)$ & $(2.04)^{* *}$ & $(0.80)$ & $(-0.42)$ \\
& 8200.299 & 0192344 & 2101241 & 46218.99 \\
Mortality & $(1.05)$ & $(0.24)$ & $(1.47)$ & $(3.08)^{* * *}$ \\
& 2.396 & 0000205 & 099029 & 11702.76 \\
Cost of & $(2.82)^{* * *}$ & $(2.31)^{* *}$ & $(3.53)^{* * *}$ & $(2.74)^{* * *}$ \\
production & 191.789 & 0018397 & 0347392 & 3996.006 \\
labour & $(2.14)^{* *}$ & $(1.99)^{*}$ & $(2.25)^{* *}$ & $(-2.51)^{* *}$ \\
& 386.0127 & 0053557 & 0681772 & -5801.338 \\
Farmsize & $(1.10)$ & $(1.46)$ & $(0.72)$ & $(-0.61)$ \\
& -116.9289 & -0004947 & 0257186 & 33.294 \\
Experience & $(-1.31)$ & $(-0.57)$ & $(0.71)$ & $(2.39)^{*}$ \\
& 1.292 & 0.011 & 0.779 & 0.001 \\
Access to loan & $(1.892)^{*}$ & $(1.409)$ & $(3.034)^{* *}$ & $(1.739)^{*}$ \\
$\mathbf{R}^{2}$ & -1.292 & -5.011 & 3.779 & 5.601 \\
$\mathbf{R}^{-2}$ & $(-1.854)^{*}$ & $(-1.809)^{*}$ & $(0.049)$ & $(1.979)^{*}$ \\
F- ratio & 0.8798 & 0.8393 & 0.8796 & 0.9036 \\
\hline Source: & 0.8552 & 0.8086 & 0.8561 & 0.8838 \\
& $35.68 * * *$ & $26.87 * * *$ & $37.43 * * *$ & $45.70 * * *$ \\
\hline
\end{tabular}

Source: field survey: 2016. Values in Parenthesis are t-ratio; + lead equation *,** and ***implies significance level at $0.10,0.05$ and 0.01 probability levels respectively

The semi-log functional form was chosen as the lead equation for farmers using the battery cage housing system. The choice of the lead equation was based on the magnitude of the coefficient of determination $\left(\mathrm{R}^{2}\right)$ the number of significant variables and the conformity of the signs borne by the coefficient variables to a priori expectation. The coefficient of determination was 0.9036 which implies that $90.36 \%$ of the variations in the profit of the battery cage users were explained by the variables included in the model. The F-ratios were significant at $1 \%$ indicating the goodness of fit of the model. 
Sex, marital status, education, mortality rate, cost of production, farm size, experience and access to credit were significant variables having varying effects on the profit of battery cage users.

Sex of the farmer was positively related to profit accrued by battery cage users at $1 \%$ significant level. This implies that male battery cage users make more profit than their female counter parts. Managing battery caged birds is demanding, strenuous and time consuming which men may adapt easily and better than their female counterparts. The male battery cage users may not employ many extra hands as they may partake in the day to day running of the farm, this helps increase the profit of the farmer as the money that would have been spent on labour is converted to profit.

Marital status was negatively significant at $1 \%$ to profit of battery cage users. This means that single farmers may generate more money than the married farmers using battery cage. Single farmers have no distractions in form of family issues and as such devote their time in caring for the birds in the cage. This may enables them to make timely interventions to avert crisis in the farm as battery cage makes for ease identification and culling of sick birds.

Education was positively related to profit at $1 \%$ level of significance. Education helps broaden the perspective of the farmers. It exposes the farmers to improved ways taking care of the birds which tend to increase their profit. This is no surprise as the farmer is exposed and open to new ideas and species may improve their farm returns. They acquire new management skills on how to manage battery caged birds which may help them minimize cost and increase profit. This finding supports Onubuogu et al. (2013) who postulated that higher level of education determines the quality of skills of farmers, their technical and allocative abilities, efficiency and how well they are informed of the innovations and technologies around them.

Morality rate was positively related to the profit of the battery cage users at $5 \%$ significant level. This implies that increase in the mortality rate also increases the income of the farmer. This is against the apriori expectation of a negative relationship.

Cost of production had negative relationship with the profit of battery caged bird farmers at $5 \%$ level of significance. This implies the lower the cost of production the higher the returns of the farmers. Battery cage system is quite efficient and reduces waste of feeds and other resources and the bird are easily cared for. It also gives the best opportunity to identify unproductive birds to be culled or given special attention. This increases the profit of the famers.

Farm size was positively related to the income of the farmer at $10 \%$ level. As the number of birds stocked by the farmer increases, the profit of the farmer increases also. This is made possible as the farmer enjoys economies of scale of bulk purchase for feeds, birds and other needed resources needed in the farm. Adeyemo (2009) and Onubuogu et al., (2014) reported that large farm size increases livestock farmers productivity, improves their technical, allocative and resource-use efficiency.

Experience was positive to profit at $10 \%$ significant level. As farmers experience increases there is a probability that his profit will increases as well. Farmers ride the experience curve 
to tackle issues as they arise in the farm. The farmers experience will help in taking decisions in the farm which will help grow the farm. This result was in line with Esiobu et al., (2014)who asserted that previous experience in agribusiness enable farmers to set realistic time and cost targets, allocate, combine, utilize resources efficiently and effectively, identify production and marketing risks.

Access to credit was significant and positively related to profit at $10 \%$ level. Access to credit facility increases the farmers' income as there is enough capital at the farmers' disposal and this helps him to run the farm better and make enough returns to meet his financial obligations.

Table 5: estimates of determinants of profit in deep litter system in the study area

\begin{tabular}{lllll}
\hline Variables & Linear $^{+}$ & Exponential & Double log & Semi log \\
\hline Intercept & 3917.75 & 10.9324 & 9.9135 & -83066.17 \\
Sex & $(2.97)^{* * *}$ & $(81.85)^{* * *}$ & $(28.68)^{* * *}$ & $(-2.28)^{* * *}$ \\
& 834.393 & 0066403 & 0665792 & 822.185 \\
Marital status & $(2.10)^{* *}$ & $(1.56)^{*}$ & $(1.89)^{*}$ & $(2.21)^{* *}$ \\
& 124.47 & 0004679 & -0161393 & 1117.941 \\
Household size & $2.08)$ & $(0.26)$ & $(-0.23)^{*}$ & $(0.15)$ \\
& 1321.197 & 0192145 & 0417308 & 1818.952 \\
Education & $(4.08)^{* * *}$ & $(2.84)^{* * *}$ & $(1.76)^{*}$ & $(0.73)$ \\
& 13284.71 & 1213066 & 1673697 & 19473.18 \\
Mortality & $(3.70)^{* *}$ & $(3.33)^{* * *}$ & $(1.89)^{*}$ & $(2.00)^{* *}$ \\
& 2.48684 & 0000218 & 1192429 & 19473.08 \\
Cost of & $(-3.25)^{* * *}$ & $(2.66)^{* *}$ & $(4.66)^{* * *}$ & $(3.14)^{* * *}$ \\
production & 215.6074 & 0019096 & 0238779 & 3005.85 \\
Labour & $(-3.19)^{* * *}$ & $(2.62)^{* * *}$ & $(1.73)^{*}$ & $(2.07)^{* *}$ \\
& 41.89 & -76.58 & 186.01 & 118.54 \\
Farm size & $(-1.40)$ & $(-0.07)$ & $(-2.05)^{* *}$ & $(2.07)^{* *}$ \\
& -89.741 & -56.64 & -91.864 & -211.364 \\
Experience & $(-1.92)^{*}$ & $(-0.63)$ & $(-0.26)$ & $(-0.62)$ \\
& 0.108 & 0.000 & 0.651 & 0.589 \\
Access to loan & $(2.432)^{* *}$ & $(-0.079)$ & $(1.442)$ & $(1.471)$ \\
R & 2.102 & -0.001 & -0.442 & -0.011 \\
$\mathbf{R}^{2}$ & $(0.759)$ & $(-1.084)$ & $(-2.133)^{*}$ & $(-1.409)$ \\
F- ratio & 0.8925 & 0.8504 & 0.8873 & 0.769 \\
\hline Source: & 0.8704 & 0.8205 & 0.8636 & 0.646 \\
& $40.46 * * *$ & $28.43 * *$ & $37.41 * * *$ & $17.25 * * *$ \\
\hline
\end{tabular}

Source: field survey; 2016. Values in Parenthesis are t-ratio; + lead equation

$*, * *$ and $* * *$ implies significance level at $0.10,0.05$ and 0.01 probability levels respectively

The linear functional form was chosen as the lead equation for farmers using deep litter housing system. The choice of the lead equation was based on the magnitude of the coefficient of determination $\left(\mathrm{R}^{2}\right)$ the number of significant variables and the conformity of the signs borne by the coefficient variables to a priori expectation. The coefficient of determination was 0.8925 which implies that $89.25 \%$ of the variations in the profit of the deep litter users were explained by the variables included in the model. The F-ratios were significant at $1 \%$ indicating the goodness of fit of the model. 
Sex, household size, education, mortality, cost of production, farm size, experience were the significant variables influencing the returns of deep litter users in the study area.

Sex was positively signed and significant at 5\% to profit of deep litter farmers. This implies that male deep litter farmers do better in terms of profit than their female counterparts. Taking care of birds under the deep litter housing system is strenuous, timing consuming and labour intensive and men tend to thrive better than women.

Household size was positively related to profit at 5\% level of significant. Large household size increases the returns of farmers using deep litter housing system. Deep litter housing is labour intensive and large household size is a proxy for cheap labour. The farmer uses their family members in the farm and this increases their returns as few paid workers are used in the farm. This findings support the result of Oluwatayo et al., (2008) who large household size compliment labour to enhance production and reduce the cost of hired labour.

Education had a positive coefficient with the returns of deep litter users and was statistically significant at $5 \%$ level of probability. It is expected that education will contribute significantly to decision making of a farmer. Exposure to high level of education is an added advantage in terms of achieving huge output, efficient marketing and sustainable production. Education opens up the farmer to new ideas and systems geared at improving the returns in the farm. This was supported by Esiobu et al., (2014) who believed that education improves farmers output.

Mortality rate was negatively related to returns at $1 \%$ significant level. This implies that as the birds mortality rate decreases, there is a probability that the farmer income increases. This is in line with the a priori expectations of the research. Low mortality rate in the farm increases the farmers' returns as they make more money selling the birds. Also the farm is efficient and the farmers can recoup the amount invested on each bird.

Cost of production was negatively signed and significant at $1 \%$ level to profit. As cost of production increases, the returns of the farmers move in the opposite direction and vice versa. Farmers using deep litter system strive to reduce cost of production by been efficient in the rationing of feeds and other resources in the farm in the bid to increase returns.

Farm size was negatively signed and significant to returns at $10 \%$ level. This is against the a priori expectation of a positive relationship. Farmers who in their bid to increase their farm size exceed the farm capacity experience poor returns as the farm house is congested. This may lead to competition among the birds for food and water. It could also lead to most of the farm birds looking so malnourished and underfeed which might lead to death of birds and easy spread of diseases in the farm.

Experience was positive to profit at 5\% significant level. As farmers experience increases his profit increases as well. Farmers ride the experience curve to tackle issues as they arise in the farm. The farmers experience will help in taking decisions in the farm which will help grow the farm. 


\subsection{Constraints of Poultry Production in the Study Area}

The farmers engaged in poultry production in the study area ranked the major problems affecting their production as shown in Table 5.

Table 5 constraints of poultry production in the study area

\begin{tabular}{lll}
\hline Constraints & Frequency & Percentage \\
\hline High cost of feeds & 136 & 97.1 \\
Inadequate fund & 120 & 85.7 \\
Lack of basic amenities & 134 & 95.7 \\
Market glut & 99 & 70.7 \\
High mortality & 50 & 35.7 \\
Quality of stock & 103 & 73.5 \\
\hline
\end{tabular}

Source: field survey; 2016. Multiple responses

Majority of the respondents $(97.1 \%)$ identified high cost of feeds as the dominant challenge faced in poultry production in the study area. This is caused by the economic recession in the country and the paucity of foreign currency in the economy. Lack of basic amenities was also a problem in the study. The respondents $(95.7 \%)$ argued that the unavailability of electricity and no good water source has increased their cost of production as many farmers rely on generator and boreholes to supply light and water to the birds. The high cost of fund has discouraged the farmers from seeking loans from financial institutions because of high interest rate. Some of the respondents (73.5\%)complained that the qualities of stock supplied are most times substandard as the source and the parent stock cannot be traced. This leads to poor growth in the birds, susceptible to pest and disease attack and in severe cases high mortality rate of farm birds. Other problems identified by the farmers were market glut and high mortality rate.

\section{CONCLUSION}

The study examined the comparative analysis of battery cage and deep litter poultry production housing systems in Abia state. Nigeria. It was observed that the cost and return analysis showed that both housing systems are profitable. However, farmers using deep litter system made more profit. It also showed that battery cage system is capital intensive when compared to deep litter system and this engenders most famers to favour deep litter housing system. The study therefore recommends that governments should subsidize the cost of feeds and other production input and make them available to the farmers in the study area. Financial institutional should be encouraged to give loans with low interest rates to farmers; this will help increase the funds available to farmers for investment. Farmers should be advised to have a good knowledge of the parent stock for making purchase. Government should provide the basic amenities in the study area; this will help drive down the cost of production.

\section{REFERENCES}

ABIA STATE ECONOMIC EMPOWERMENT AND DEVELOPMENT STRATEGY
(2003) Abia State of Nigeria 
ACIAR, 2009. Improving village chicken production: A manual field workers and trainers, The Australian Centre for International Agricultural Research (ACIAR), Monograph series. $3031 \mathrm{pp}$

ADEBAYO, C.O., OSEGHALE, A. I. AND ADEWUMI, A. A.(2015)Profitability and technical efficiency among broiler farmers in kwara state, Nigeria: Nigerian Journal of Agriculture, Food and Environment. 11(2):92-96.

ADEYEMO, A A (2009). Problems militating against commercial egg production in southern Guinea savannah of Nigerian. Proceeding of the Annual conference of Animal science of Nigeria September 14th-19th, 2009. LAU-TECH Ogbomoso, Nigeria Mp: 304.

ALADEJEBI O J, OKOJIE O L, AND AFOLAMI C A. (2014) comparative production efficiency of egg farming battery cage and deep litter system in the drive towards sustainable poultry (Volume 16, in Ogun state, NigeriaJournal of Sustainable Development in Africa Pennsylvania No.4,2014) ISSN: 1520-5509 Clarion University of Pennsylvania, Clarion,

ESIOBU, N.S; G.C ONUBUOGU AND V.B.N OKOLI (2014) Determinants of Income from Poultry Egg Production in Imo State, Nigeria: An Econometric Model Approach:Global Advanced Research Journal of Agricultural Science (ISSN: 2315-5094) Vol. 3(7) pp. 186-199, July, 2014. Available online http://garj.org/garjas/index.htm

http://www.agritech.tnau.ac.in/animal_husbandry/ani_chik_poultry\%20rearing.html http://www.practicalbusinessideas.com/deep-litter-vs-battery-cage-floor-rearing-or-cagesystem/

LAMID W.A (2014) Comparative Analysis of Broilers' Rearing in Different Housings Systems in Wet Humid Climate, South West Nigeria Journal of Biology, Agriculture and Healthcare Vol.4, No.20 www.iiste.org ISSN 2224-3208 ISSN 2225-093X (Online)

MGBAKOR, M. N AND NZEADACHIE, E. S. (2013). Economic Analysis of Broiler Production (A Case study of Orumba South LGA of Anambra State, Nigeria. American-Eurasian Journal of Agronomy, 6(2):25-31.

NIGERIAN BUREAU OF STATISTICS. (2010) "Labour Force Statistics, 2010". Retrieved 22 June 2015

OGBU C.C, JOSEPH T.J \& NWOSU C.C (2015) Comparative egg production performance of domestic chicken genotypes reared in two housing plans and feeding regimens. Global journal of biology, agriculture and health sciences. Vol.4(1) ISSN: 2319 - 5584 257

OKEZIE, C. A. AND BIME, M. A. (2006). Empirical Analysis of Broiler Production Function in Calabar, Cross Rivers State Nigeria. Research Journal of Biological Sciences, 1(1-4):28 31 . 
OLUWATAYO, I B, SEKUMADE A B, ADESOJI S A (2008). Resource use Efficiency of Maize Farmers in rural Nigeria. Evidence from Ekiti State, World J. Agric. Sci. 4(1): 91-99.

ONUBUOGU, G C, CHIDEBELU SAND, EBOH E C (2013). Enterprise Type, Size and Allocative Efficiency of Broiler Production in Imo State, Nigeria. Inter. J. Applied Res. And Technol., 2(6): $10-19$. 